\title{
Substitusi Titonia (Tithonia diversifolia) dengan Baglog Pelepah Sawit yang Difermentasi dengan Pleurotus ostreatus terhadap Ketersediaan Mineral Makro pada Kambing Peranakan Etawa (PE)
}

\section{Substitution of Titonia (Tithonia diversifolia) with Baglog Palm Fronds Fermented with Pleurotus ostreatus for the Biovailability of Macro Minerals in the Peranakan Etawa (PE) Goat}

\author{
R. Rianita ${ }^{1 *}$, Y. Metri ${ }^{1}$, Evitayani ${ }^{2}$, dan L. Warly ${ }^{2}$ \\ ${ }^{1}$ Program Pascasarjana, Fakultas Peternakan, Universitas Andalas, Padang \\ ${ }^{2}$ Program Studi Peternakan, Fakultas Peternakan, Universitas Andalas, Padang \\ *E-mail: resti.rianita@gmail.com
}

(Diterima: 24 Juli 2019; Disetujui: 27 September 2019)

\begin{abstract}
ABSTRAK
Penelitian bertujuan untuk mengetahui pengaruh pemberian Titonia (Tithonia diversifolia) dan limbah baglog pelepah sawit dari budidaya jamur tiram putih (Pleoratus ostreatus) terhadap kecernaan bahan kering $(\mathrm{KcBK})$ dan kecernaan bahan organik $(\mathrm{KcBO})$, serta ketersediaan mineral makro pada kambing PE. Penelitian ini menggunakan metode eksperimen Rancangan Acak Kelompok dengan 4 kali ulangan. Perbandingan antara hijauan dan konsentrat adalah 60 : 40. Perlakuan dalam penelitian ini adalah: $\mathrm{A}=0 \%$ Baglog $+40 \%$ Konsentrat $+60 \%$ Titonia, $\mathrm{B}=20 \%$ Baglog $+40 \%$ Konsentrat $+40 \%$ Titonia, $\mathrm{C}$ $=30 \%$ Baglog $+40 \%$ Konsentrat $+30 \%$ Titonia, dan D $=40 \%$ Baglog $+40 \%$ Konsentrat $+20 \%$ Titonia. Parameter yang diamati dalam penelitian ini adalah; kecernaan bahan kering (BK) dan bahan organik (BO), ketersediaan hayati (bioavailability) mineral makro (Ca, P, Mg, S). Pada penelitian ini menunjukkan hasil bahwa pemberian titonia yang disubstitusikan dengan baglog pelepah sawit memberikan pengaruh sangat nyata $(\mathrm{P}<0,01)$ terhadap $\mathrm{KcBK}(64,59 \%)$ dan $\mathrm{KcBO}(59,73 \%)$. Mineral makro $\mathrm{Ca}, \mathrm{P}, \mathrm{Mg}$ dan $\mathrm{S}$ memiliki Biovailabilitas sebesar $(68,30 \%, 72,55 \%, 71,40 \%, 73,49 \%)$. Peningkatan level baglog pelepah sawit hingga $40 \%$ masih memberikan nilai kecernaan yang baik terhadap kecernaan BK dan BO, serta masih dapat menyediakan kebutuhan mineral makro diatas $60 \%$ dari total elemen yang dikonsumsi.
\end{abstract}

Kata kunci: ketersediaan, mineral, pelepah sawit fermentasi, titonia

\section{ABSTRACT}

The aim of this research was evaluate the effect of Titonia (Tithonia diversifolia) and spent mushroom (Pleurotus ostreatus) substrate made from palm fronds supplementation on dry matter (DM) and organic matter (OM) digestibility, and bioavailability of macro minerals in PE goats. This experimental method used Randomized Block Design with 4 replications for each treatment. The ratio between forage and concentrate is 60: 40. The forage consisted of the different level between spent mushroom substrate(SMS) from palm fronds and titonia. The treatments of this study were: $A=0 \%$ Baglog $+40 \%$ Concentrate $+60 \%$ Tihtonia , $B=20 \%$ Baglog $+40 \%$ Concentrate $+40 \%$ Tithonia, $C=30 \%$ Baglog $+40 \%$ Concentrate + $30 \%$ Tithonia, and D $=40 \%$ Baglog $+40 \%$ Concentrate $+20 \%$ Tithonia. The parameters observed were; $D M$ and OM digestibility, and bioavailability of macro minerals (Ca, $P, M g, S)$. The results showed that the treatment high significant effect $(P<0.01)$ on the digestibility of DM digestibility $(64.59 \%)$ and $O M$ digestibility (59.73\%), minerals bioavailability of $\mathrm{Ca}, \mathrm{P}, \mathrm{Mg}$ and $\mathrm{S}$ (68.30\%, 72.55\%, 71.40\%, 73.49\%). The application of baglog level at 40\% still had a good digestion value for DM and OM digestibility and macro minerals bioavailability above $60 \%$ of the total elements consumed.

Keywords: availability, fermented palm frond, mineral, tithonia 


\section{PENDAHULUAN}

Ketersediaan hijauan yang semakin menurun diakibatkan karena berkurangnya ketersediaan lahan terbuka yang dimanfaatkan untuk sektor pembangunan dan kecendrungan dari petani untuk menanam tanaman pangan. Solusi untuk menanggulagi kekurangan pakan ternak ruminansia adalah dengan pemanfaatan pakan alternatif. Salah satu hijauan pakan alternatif yang cukup potensial adalah Titonia dan pelepah sawit.

Titonia(Tithonia diversifolia) adalah tanaman jenis legum yang banyak tumbuh dipinggir jalan dan sering dianggap sebagai gulma padahal tanaman ini dapat dimanfaatkan sebagai pakan. Menurut Jamarun et al. (2017) tanaman titonia memiliki kandungan protein kasar dan serat kasar sebesar 22,98\% dan 18,17\%. Pelepah sawit merupakan limbah perkebunan kelapa sawit yang diperoleh dari panen tandan buah segar (TBS) dan dapat tersedia sepanjang tahun. Potensi pengembangan kelapa sawit, ditinjau dari luas areal perkebunan kelapa sawit di Indonesia tahun 2015 diperkirakan mencapai $11.300 .370 \mathrm{Ha}$ dan terus meningkat setiap tahunnya (BPS, 2015). Namun, pembatas yang paling signifikan dalam pemanfaatan pelepah sawit sebagai sumber pakan adalah kandungan lignin dan kadar serat kasar yang tinggi sehingga menurunkan nilai kecernaan (Febrina et al., 2016; Zain et al., 2014). Untuk mengatasi hal tersebut perlu dilakukannya bioteknologi pengolahan pakan yang ramah lingkungan salah satunya seperti pemanfaatan Pleurotus ostreatus atau jamur tiram putih sebagai agen biodelignifikasi, hal ini tidak lepas dari peranan enzim lignolitik yang dihasilkannya seperti lignin peroksidase (LiP), lakase (Lac), dan mangan peroksidase (MnP) (Datta et al., 2017).

Baglog merupakan tempat media tanam yang digunakan dalam budidaya Pleurotus ostreatus. Umumnya media baglog yang digunakan adalah serbuk gergaji dan jerami padi. Limbah media tumbuh berupa baglog ini masih memiliki sisa-sisa kandungan nutrisi yang belum termanfaatkan untuk memproduksi tubuh buah Pleurotus osteratus secara maksimal lagi. Biasanya baglog tersebut hanya dimanfaatkan sebagai kompos atau dibakar, padahal jika dilihat dari bahan penyusun yang terkandung dalam baglog tersebut, maka dapat dimanfaatkan sebagai sumber serat untuk pakan ternak ruminansia sehingga dapat memasok kebutuhan energi serta menyediakan berbagai mineral yang dibutuhkan oleh mikroba rumen maupun maupun ternak itu sendiri. Menurut Metri (2019) pengaruh dosis dan lama fermentasi pelepah sawit memberikan pengaruh yang berbeda tidak nyata terhadap ketersedian mineral sebelum dan sesudah fermentasi. Namun, dari hasil rerata pelepah sawit yang telah difermentasi dengan Pleoratus ostreatus menunjukkan peningkatan Mineral $\mathrm{Ca}(80 \%)$, P (8\%), Mg (20\%), dan S (17\%).

Mineral merupakan salah satu zat yang memiliki peranan penting dalam metabolisme tubuh, pertumbuhan dan reproduksi ternak. Umumnya secara alami, ternak mendapat mineral yang berasal dari dalam tanaman atau pakan hijauan, namun kandungan mineral dalam hijauan jarang mengandung semua mineral yang dibutuhkan oleh hewan (Warly et al., 2017). Pemanfaatan pelepah sawit sebagai substrat penyusun baglog umumnya jarang digunakan sebagai pengganti hijauan sehingga perlu dikaji dan dilakukan penelitian ini dalam hal ketersediaan mineral.

\section{METODE}

Penelitian ini dilaksanakan di Rantiang Ameh Farm. Kambing yang digunakan dalam penelitian ini Jenis Kambing Peranakan Etawa (PE) jantan, dengan jumlah sebanyak 16 ekor dengan bobot badan $30-50 \mathrm{Kg}$ dan umur 10-12 bulan. Penelitian ini menggunakan Rancangan Acak Kelompok (RAK). Setiap kelompok atau blok terdiri dari 4 kambing, diatur sesuai bobot tubuh. Komposisi ransum percobaan adalah sebagai berikut:

$\mathrm{A}=0 \%$ Baglog $+40 \%$ Konsentrat $+60 \%$ 
Titonia

$\mathrm{B}=20 \%$ Baglog $+40 \%$ Konsentrat $+40 \%$ Titonia

$\mathrm{C}=30 \%$ Baglog $+40 \%$ Konsentrat $+30 \%$
Titonia

$\mathrm{D}=40 \%$ Baglog $+40 \%$ Konsentrat $+20 \%$ Titonia

Fermentasi perbanyakan baglog

Tabel 1. Kandungan nutrisi bahan penyusun ransum

\begin{tabular}{lrrrrrrrr}
\hline \multirow{2}{*}{ Bahan Pakan } & \multicolumn{8}{c}{ Kandungan zat-zat Makanan (\%) } \\
\cline { 2 - 9 } & BK & BO & PK & LK & SK & BETN & TDN & Abu \\
\hline Ampas Tahu & 9,15 & 97,01 & 18,80 & 3,0 & 23,00 & 52,21 & 69,68 & 2,99 \\
Dedak Halus & 91,02 & 86,03 & 6,26 & 1,0 & 26,00 & 52,77 & 55,30 & 13,97 \\
Bungkil Kelapa & 90,55 & 97,01 & 10,18 & 10,0 & 15,00 & 61,83 & 78,35 & 2,99 \\
Titonia & 25,57 & 96,72 & 22,98 & 5,8 & 18,17 & 49,77 & 72,54 & 3,28 \\
Baglog Pelepah Sawit & 46,27 & 77,00 & 16,45 & 1,0 & 29,00 & 30,55 & 45,71 & 23,00 \\
\hline
\end{tabular}

Tabel 2. Persentase formulasi ransum penelitian

\begin{tabular}{lrrrr}
\hline \multirow{2}{*}{ Bahan Penyusun Ransum } & \multicolumn{4}{c}{ Formulasi Ransum Penelitian (\%) } \\
\cline { 2 - 5 } & $\mathrm{A}$ & $\mathrm{B}$ & $\mathrm{C}$ & $\mathrm{D}$ \\
\hline Ampas Tahu & 30,0 & 30,0 & 30,0 & 30,0 \\
Dedak Halus & 7,5 & 7,5 & 7,5 & 7,5 \\
Bungkil Kelapa & 2,5 & 2,5 & 2,5 & 2,5 \\
Titonia & 60,0 & 40,0 & 30,0 & 20,0 \\
Baglog Pelepah Sawit & 0,0 & 20,0 & 30,0 & 40,0 \\
\hline Total & 100,0 & 100,0 & 100,0 & 100,0 \\
\hline
\end{tabular}

Tabel 3. Komposisi kimiawi nutrisi ransum perlakuan

\begin{tabular}{lrrrr}
\hline Kandungan Nutrisi (\%) & Ransum A & Ransum B & Ransum C & Ransum D \\
\hline BK & 27,18 & 31,32 & 33,39 & 35,46 \\
BO & 96,01 & 92,07 & 90,10 & 88,12 \\
PK & 20,15 & 18,85 & 18,19 & 17,54 \\
LK & 4,71 & 3,74 & 3,27 & 2,79 \\
SK & 20,13 & 22,29 & 23,38 & 24,46 \\
Abu & 3,99 & 7,93 & 9,90 & 11,88 \\
BETN & 51,03 & 47,18 & 45,26 & 43,34 \\
TDN & 70,53 & 65,17 & 62,48 & 59,80
\end{tabular}

Keterangan: Dihitung berdasarkan Tabel 1 dan Tabel 2.

Tabel 4. Kandungan mineral dalam ransum penelitian

\begin{tabular}{lrrrr}
\hline Mineral & Ransum A & Ransum B & Ransum C & Ransum D \\
\hline $\mathrm{Ca}$ & 1,83 & 1,73 & 1,73 & 1,72 \\
$\mathrm{P}$ & 0,73 & 0,71 & 0,71 & 0,69 \\
$\mathrm{Mg}$ & 2,11 & 2,01 & 2,00 & 1,98 \\
$\mathrm{~S}$ & 0,08 & 0,08 & 0,07 & 0,07 \\
\hline
\end{tabular}


pelepah sawit dengan memanfaatkan jamur tiram putih (Pleurotus ostreatus) dengan dosis terbaik yaitu $0,7 \%$ dan lama fermentasi 3 bulan berdasarkan hasil penelitian (Metri et al., 2018). Pada waktu fermentasi 3 bulan baglog sudah tidak maksimal lagi dalam menghasilkan tubuh buah jamur dan kandungan nutrisi dalam baglog belum habis termanfaatkan semua dengan ditambah dati sisa biomassa Pleurotus ostreatus yang kaya sumber protein sehingga dapat dijadikan bahan pakan.

Komposisi konsentrat terdiri dari ampas tahu, bungkil kelapa, dan dedak halus tidak ada suplemen mineral yang diberikan dalam penelitian ini. Ransum penelitian disusun berdasarkan kebutuhan bahan kering yaitu 2,5 $\%$ dari bobat badan (Church, 1980).

Ransum penelitian di berikan pada pagi hari pukul 07.00 dan sore hari pukul 16.00. Pakan yang tidak dikonsumsi atau sisa ditimbang setiap hari sebelum makan pagi. Total kotoran atau fases selama 5 hari dikumpulkan dan dikomposit, selanjutnya $10 \%$ dari total fases dikeringkan dalam oven selama 24 jam pada suhu $60^{\circ} \mathrm{C}$. Sampel dikomposit dan dihaluskan untuk analisis lebih lanjut. Analisis laboratorium: Komposisi kimia dari pakan dan fases dianalisis sesuai dengan metode AOAC (1990). Konsentrasi mineral yang diukur yaitu; $\mathrm{Ca}, \mathrm{P}, \mathrm{Mg}$, dan $\mathrm{S}$, ditentukan dengan menggunakan metode Inductively Coupled Plasma (ICP) dengan prinsip unsur-unsur yang memancarkan karateristik cahaya dengan panjang gelombang jenis yang bisa diukur. Alat yang digunakan ICPE- 9000 Shimadzu.

Pengukuran Kecernaan Zat Makanan dan Bioavaibilitas Mineral 1970):

Perhitungan nilai kecernaan (Harris,

Perhitungan KcBK (\%):

$\frac{\text { Konsumsi BK }(\mathrm{g})-\text { BK Feses }(\mathrm{g})}{\text { Konsumsi BK }(\mathrm{g})} \times 100 \%$
Perhitungan KcBO (\%):

$\frac{\text { Konsumsi B0 (g) - B0 Feses (g) }}{\text { Konsumsi B0 (g) }}$ X $100 \%$

Bioavailabilitas Mineral (\%):

$\frac{\text { Mineral dikonsumsi }(\mathrm{g} / \mathrm{Kg} \mathrm{BK}) \text {-Mineral di feses }(\mathrm{g} / \mathrm{Kg} \mathrm{BK})}{\text { Mineral dikonsumsi }(\mathrm{g} / \mathrm{Kg} \mathrm{BK})} \times 100 \%$

\section{Analisa Statistik}

Rancangan yang digunakan adalah Rancangan Acak Kelompok (RAK) dengan model matematis sebagai berikut:

$$
\boldsymbol{Y i j}=\mu+\tau i+\boldsymbol{\beta} \boldsymbol{j}+\Sigma i j
$$

Keterangan:

Yi $=$ hasil pengamatan perlakuan ke-i dan kelompok ke-j

$\mu=$ nilai tengah umum

$\tau i=$ pengaruh perlakuan ke- $\mathrm{i}$

$\mathrm{Bj}=$ pengaruh kelompok ke-j

$\Sigma i j=$ pengaruh sisa dari perlakuan ke-i dan kelompok ke-j

I = banyak perlakuan $(1,2,3,4$,

$\mathrm{J} \quad=$ kelompok $(1,2,3,4)$

Selanjutnya data yang diperoleh dianalisis sidik ragam, apabila hasil analisis ragam menunjukkan pengaruh nyata maka dilakukan uji lanjut dengan Duncan's Multiple Range Test (DMRT) (Steel and Torrie, 1980).

\section{HASIL DAN PEMBAHASAN}

\section{Kecernaan Bahan Kering (KcBK) dan} Kecernaan Bahan Organik (KcBO)

Penambahan baglog pelepah sawit difermentasi dengan jamur Pleurotus ostreatus memberikan berpengaruh sangat nyata $(\mathrm{P}<0,01)$ terhadap kecernaan bahan kering $(\mathrm{KcBK})$ dan kecernaan bahan organik (KcBO) (Tabel 5). Pada penelitian ini didapatkan bahwa kecernaan $\mathrm{BK}$ dan $\mathrm{BO}$ Perlakuan A berbeda sangat nyata $(P<0,01)$ terhadap perlakuan $\mathrm{B}, \mathrm{C}$ dan $\mathrm{D}$, sedangkan perlakuan $\mathrm{B}$ berdeda tidak nyata $(\mathrm{P}>0,05)$ dengan perlakuan $\mathrm{C}$ dan $\mathrm{D}$ terhadap kecernaan BK. Penambahan baglog pelepah sawit 
Tabel 5. Kencernaan bahan kering dan Kecernaan bahan organik

\begin{tabular}{lcc}
\hline Perlakuan & Kecernaan Bahan Kering (\%) & Kecernaan Bahan Organik (\%) \\
\hline A & $87,12^{\mathrm{a}} \pm 2,39$ & $86,03^{\mathrm{a}} \pm 1,86$ \\
$\mathrm{~B}$ & $67,83^{\mathrm{b}} \pm 7,42$ & $66,50^{\mathrm{b}} \pm 7,56$ \\
$\mathrm{C}$ & $66,77^{\mathrm{b}} \pm 7,47$ & $63,14^{\mathrm{bc}} \pm 6,05$ \\
$\mathrm{D}$ & $64,59^{\mathrm{b}} \pm 6,71$ & $56,18^{\mathrm{c}} \pm 6,12$ \\
\hline SE* & 1,08 & 1,42 \\
\hline
\end{tabular}

Keterangan: Huruf yang berbeda pada kolom yang sama menunjukkan perlakuan berbeda sangat nyata $(\mathrm{P}<0,01) . *$ Standar Error dari rata-rata $(\mathrm{SE}=$ Standard error $)$

berpengaruh sangat nyata $(\mathrm{P}<0,01)$ terhadap kecernaan bahan organik. Setelah dilakukan uji lanjut menunjukkan bahwa perlakuan A berbeda sangat nyata dengan perlakuan $\mathrm{B}$, $\mathrm{C}$, dan $\mathrm{D}$, sedangakan perlakuan $\mathrm{B}$ berbeda tidak nyata dengan $\mathrm{C}$, dan perlakuan $\mathrm{C}$ tidak berbeda nyata dengan $\mathrm{D}$.

Berdasarkan hasil rataan dari nilai kecernaan menunjukkan bahwa ransum A memiliki tingkat kecernaan $\mathrm{BK}$ yang paling tinggi jika dibandingkan perlakuan lain $(\mathrm{B}, \mathrm{C}$, dan D) yaitu sebesar $87,12 \%$. Dari tabel 5 diatas dapat dilihat bahwa rataan KcBK berkisar antara $64,59 \% \quad-87,12 \%$. Nilai kecernaan BK suatu bahan pakan menggambarkan kualitas bahan pakan tersebut sedangkan nilai kecernaan yang rendah menunjukkan rendahnya kualitas nutrisi dari bahan pakan tersebut. Tingginya KcBK pada perlakuan A disebabkan karena ransum A terdiri atas $60 \%$ Titonia yang memiliki kandungan SK yang rendah dan PK yang tinggi (Tabel 3) jika dibandingkan perlakuan lainnya. Hal ini dikarenakan semakin rendahnya kandungan serat kasar dalam suatu bahan pakan pakan maka mikroba rumen semakin mudah mendegradasi pakan tersebut sehingga proses pencernaan akan meningkat dan kecernaan BK juga meningkat.

Menurunnya nilai KcBK ransum perlakuan disebabkan oleh kandungan serat kasar yang cendrung meningkat. Kandungan serat kasar perlakuan A, B, C dan D berkisar antara 20,13\%- 24,45\% (Tabel 3), dimana kandungan SK perlakuan A paling rendah yaitu $20,13 \%$. Semakin rendahnya kandungan serat kasar dalam ransum maka KcBK ransum tersebut akan semakin meningkat, dan sebaliknya semakin tingginya serat kasar dalam suatu bahan pakan maka KcBK suatu pakan tersebut akan semakin menurun. Hal ini sesuai dengan pendapat Anggorodi (1994) yang menyatakan bahwa, semakin banyaknya serat kasar yang terdapat dalam suatu bahan pakan semakin tebal dan semakin tahan dinding sel dan akibatnya semakin rendah daya cernanya suatu bahan pakan tersebut. Kecernaan dari zat-zat makanan suatu bahan pakan sangat menentukan kualitas pakan tersebut, karena akan diketahui berapa persen yang dicerna dan yang akan dikeluarkan melalui fases (Coleman dan Moore, 2003). Secara umum kecernaan BK dari hasil penelitian ini masih cukup baik sehingga zat makanan dapat dimanfaatkan secara optimal oleh ternak bahwa. Hal ini disebabkan karena baglog pelepah sawit hasil fermentasi dengan jamur tiram putih digiling halus dan dicampurkan dengan konsentrat sehingga mengurangi penolakan ternak kambing $\mathrm{PE}$ terhadap pelepah sawit yang telah difermentasi dengan Pleurotus osteratus. Ukuran partikel pakan ini juga mempengaruhi degradasi pakan oleh enzim yang dihasilkan mikroba.

Berdasarkan hasil analisis kecernaan bahan organik (KcBO) menunjukkan bahwa nilai $\mathrm{KcBO}$ sejalan dengan nilai $\mathrm{KcBK}$ hal ini dikarenakan sebagian besar dari bahan kering merupakan bahan organik hanya saja yang membedakannya adalah kandungan bahan anorganik (abu) (Tabel 5). Tingginya kecernan bahan organik pada perlakuan A, 
Tabel 6. Rataan bioavailability mineral makro (\%)

\begin{tabular}{lcccc}
\hline Perlakuan & $\begin{array}{c}\text { Bioavailability Ca } \\
(\%)\end{array}$ & $\begin{array}{c}\text { Bioavailability P } \\
(\%)\end{array}$ & $\begin{array}{c}\text { Bioavailability Mg } \\
(\%)\end{array}$ & $\begin{array}{c}\text { Bioavailability S } \\
(\%)\end{array}$ \\
\hline A & $88,14^{\mathrm{a}} \pm 2,37$ & $90,95^{\mathrm{a}} \pm 1,25$ & $89,29^{\mathrm{a}} \pm 1,63$ & $91,14^{\mathrm{a}} \pm 1,63$ \\
$\mathrm{~B}$ & $71,34^{\mathrm{b}} \pm 7,22$ & $75,47^{\mathrm{b}} \pm 5,42$ & $72,80^{\mathrm{b}} \pm 7,75$ & $74,20^{\mathrm{b}} \pm 7,75$ \\
$\mathrm{C}$ & $69,18^{\mathrm{b}} \pm 1,42$ & $74,18^{\mathrm{b}} \pm 5,10$ & $72,59^{\mathrm{b}} \pm 5,81$ & $75,37^{\mathrm{b}} \pm 5,81$ \\
$\mathrm{D}$ & $68,30^{\mathrm{b}} \pm 5,39$ & $72,55^{\mathrm{b}} \pm 5,01$ & $71,40^{\mathrm{b}} \pm 4,51$ & $73,49^{\mathrm{b}} \pm 4,51$ \\
\hline SE $^{*}$ & 1,54 & 0,85 & 0,88 & 0,90 \\
\hline
\end{tabular}

Keterangan: Huruf yang berbeda pada kolom yang sama menunjukkan berbeda sangat nyata $(\mathrm{P}<0,01)$. *Standar Error dari rata-rata.

dikarena jika dibandingkan dengan perlakuan lainnya kandungan protein kasarnya lebih tinggi (Tabel 3). Meningkatnya kecernaan bahan organik pada pakan juga dipengaruhi oleh kandungan protein kasar dalam pakan tersebut. Hal ini sesuai pendapat Sutardi (1980) penambahan bahan pakan yang mengandung protein kasar yang tinggi memberikan indikasi bahwa protein mempengaruhi pemanfaatan zat makanan lainnya, sehinnga meningkatkan jumlah bakteri proteolitik dan naiknya deaminasi yang nantinya juga akan meningkatkan nilai kecernaan bahan organik.

\section{Bioavailability Mineral Makro}

Perlakuan pemberian baglog pelepah sawit yang di fermentasi dengan Pleurotus ostreatus memberikan pengaruh berbeda sangat nyata $(\mathrm{P}<0,01)$ terhadap bioavailability mineral makro $\mathrm{Ca}, \mathrm{P}, \mathrm{Mg}$, dan $\mathrm{S}$ (Tabel 6). Berbeda tidak nyatanya $(\mathrm{P}>0,05)$ dengan perlakuan $\mathrm{B}, \mathrm{C}$, dan perlakuan $\mathrm{D}$ hal disebabkan kandungan mineral yang relatif sama dalam ransum penelitian. Secara keseluruhan, bioavailabilitas mineral yang dievaluasi tersebut elemen berada di atas $60 \%$ dari elemen dikonsumsi. Hal ini menunjukkan bahwa ransum yang terdiri dari baglog pelepah sawit dan titonia dapat menyediakan mineral makro bagi kebutuhan kambing PE. Secara keseluruhan pemberian baglog pelepah sawit sebanyak $20 \%, 30 \%$, dan $40 \%$ masih dapat menyediakan kebutuhan mineral makro $(\mathrm{Ca}$, P, Mg, dan S) sebanyak 68,30\%- 91,14\%.

Tingginya bioavailabilitas mineral makro (Ca, P, Mg dan S) pada perlakuan
A disebabkan oleh rendahnya kandungan lignin pada ransum perlakuan menyebabkan meningkatkan kecernaan bahan kering. Semakin tinggi KcBK (Tabel 6) dan rendahnya kandungan serat kasar (Tabel 3) dalam pakan maka lebih banyak konsentrasi mineral tambahan yang tersedia dengan melepaskan mineral yang terikat pada serat. Pada penelitian yang dilakukan Pazla (2018) kandungan lignin pada titonia hanya mencapai 4,57\% jika dibandingkan baglog pelepah sawit yang kandungan ligninnya mencapai $15,7 \%$. Mineral yang tersedia dalam hijauan akan menempel pada dinding sel tanaman. Menurut Evitayani et al. (2006) kandungan konstituen dinding sel yang tinggi (NDF dan ADF) serta serat kasar dalam hijauan dikaitkan dengan terikatnya komponen anorganik lebih banyak ke dinding sel tanaman dan bisa mengurangi ketersediaan mineral untuk ternak. Secara keseluruhan pemberian baglog pelepah sawit sebanyak $20 \%, 30 \%$, dan $40 \%$ masih dapat menyediakan kebutuhan mineral $\mathrm{Ca}$ sebesar 68,30\%-70,01\%.

Mineral Ca pada baglog diduga berasal dari kalsium karbonat yang dipakai pada saat fermentasi pelepah sawit, selain itu baglog yang sudah difermentasi selama tiga bulan kandungan SK pada pelepah sawit juga mengalami penurunan sehingga $\mathrm{Ca}$ lebih mudah tersedia. Emanuele dan Staples (1990), melaporkan mineral yang terkait dengan dinding sel tanaman memiliki bioavailabilitas yang lebih rendah atau memerlukan waktu fermentasi yang lebih lama untuk pelepasan yang maksimal. Tingginya ketersediaan $\mathrm{P}$ 
pada perlakuan A dikarenakan P yang terikat fitat pada tanaman Titonia sudah didegradasi oleh enzim phytase yang dihasilkan oleh mikroba rumen. Hal ini sesuai pendapat Lamid (2012) pada ternak ruminansia ikatan fitat dan mineral fosfor $(\mathrm{P})$ dapat dipecah oleh enzim phytase yang dihasilkan bakteri rumen seperti Actinobacillus dan Bacillus pumilus. Pada ternak ruminansia mineral $\mathrm{P}$ juga dibutuhkan dalam proses pertumbuhan sel mikroba rumen sehingga dapat mencerna serat secara maksimal terutama dilakukan oleh bakteri selulolitik serta membantu menstimulir produksi VFA (Rukebusch dan Stivend, 1980). Selain itu faktor-faktor yang mempengaruhi ketersediaan mineral bagi ternak adalah jenis tanah dimana ternak tersebut dipelihara karena akan mempengaruhi ketersediaan mineral yang akan diserap oleh tanaman. Sesuai dengan pendapat Aminuddin (1999) kandungan mineral dalam hijauan sangat bervariasi tergantung kadar mineral tanah, iklim, spesies tanaman, pengelolaan tanaman, umur pemotongan dan produksi hijauan tempat ternak dipelihara. Ketersediaan mineral $\mathrm{Mg}$ dalam suatu bahan pakan mungkin sebagian disebabkan oleh perbedaan dari afinitas unsur-unsur mineral dalam dinding sel, yang bisa mempengaruhi kelarutannya, seperti yang dinyatakan Ibrahim et al. (1990) nilai bioavailabilitas elemen tertentu yang tinggi menunjukkan afinitas elemen tersebut dari dinding sel lebih rendah, sehingga elemen tersebut lebih banyak tersedia untuk ternak. Pada tanaman hujauan kandungan mineral $\mathrm{S}$ dapat berkisar dari $0,04 \%$ sampai melebihi $0,3 \%$. Menurut Piliang (2002), kandungan protein kasar yang tinggi pada suatu bahan pakan biasanya memiliki kandungan mineral $\mathrm{S}$ yang tinggi pula. Sulfur merupakan unsur penting yang diperlukan dalam sintesis beberapa asam amino. Menurut McDonald et al. (2002) defisiensi S mengakibatkan terganggunya pertumbuhan ternak hal ini dikarenakan $\mathrm{S}$ memiliki peranan penting dalam membentuk protein mikroba.

\section{KESIMPULAN}

Peningkatan level baglog pelepah sawit hingga $40 \%$ masih memberikan nilai kecernaan yang baik terhadap kecernaan BK dan BO, serta masih dapat menyediakan kebutuhan mineral makro diatas $60 \%$ dari total elemen yang dikonsumsi.

\section{DAFTAR PUSTAKA}

AOAC, 1990. Official Methods of Analysis. 15th Edn., Association of Official Analytical Chemist, Washington, DC., USA Pages: 684.

Aminuddin, P. 1999. Ilmu Nutrisi dan Makanan Ternak Ruminansia. UI Press. Jakarta.

Anggorodi, R. 1994. Ilmu Makanan Ternak Umum. PT. Gramedia. Jakarta.

Badan Pusat Statistik [BPS]. 2015. Statistik Kelapa Sawit Indonesia 2015. Badan Pusat Statistik, Jakarta.

Church, D. C. and W. G. Pond. 1980. Basic Animal Nutrition and Feeding. 2"d Ed John Willey and Sons. New York.

Coleman, S. W. and J. E. Moore. 2003. Feed Quality and Performance. Field Corps Res. 84: 17-29.

Datta, R., A. Kelkar., D. Baraniya., A. Molaei., A. Moulick., R. S. Meena, and P. Formanek. 2017. Enzymatic degradation of lignin in soil: A review. Sustainability, Vol. 9, No. 7. 10.3390/ su9071163.

Febrina, D., N. Jamarun., M. Zain, and Khasrad. 2017. The Effect of P, S, and $\mathrm{Mg}$ Suplementation of Oil Palm Fronds Fermented by Phanerochaete chrysosporium on Rumen Fluid Characteristics and Microbial Protein Syinthesis. Pak. J. Nutr. 13(3): 299304.

Emanuele, S. M. and C. R. Staples. 1990. Ruminal release of minerals from six forage species. J. Anim. Sci., 68: 2052- 
2060.

Evitayani., L. Warly., A. Fariani., T. Ichinohe., M. Hayashida., S. A. Abdul Razak, and T. Fujihara. 2006. Macro mineral distribution of forages in South Sumatra during rainy and dry seasons. Journal of Food, Agriculture \& Environment JFAE, Vol. 4 (2): 155 - 160.

Harris, L. E. 1970. Nutrition Research Technique for Domestic and Wild Animal. Vol 1. An International Record System and Procedur for Analyzing Sample. Animal Science Department. Utah State University. Logan. Utah.

Ibrahim, M. N. M., A. Van der Kam., G. Zammelink, and S. Tamminga. 1990. Solubility of mineral element present in ruminant feeds. J. Agric.Sci., 114: 265- 274.

Jamarun, N., Elihasridas., R. Pazla, and Fitriyani. 2017. In vitro nutrients digestability of the combinations titonia (Tithonia difersivolia) and Naiper grass (Pennisetum purpureum). Procedings of the 7th international Seminar on Tropical Animal Production. Yogyakarta. Indonesia.

Lamid, M. 2012. Karakteristik Enzim Fitase Asal Bakteri Rumen (Actinobacillus dan Bacillus pumilus) dan Analisis SEM terhadap Perubahan Struktur Permukaan Dedak Padi untuk Ransum Ayam Broiler. Unair. (Unpublished).

Metri, Y., L. Warly, and Suyitman. 2018. Biodegradation of lignin by white rot fungi (Pleurotus ostreatus) to decrease the fibre components in the palm midrib. Pakistan Journal of Nutrition. Vol. 17 No. $2: 71$ - 75.

Metri, Y. 2019. Biodegradasi Lignin Melalui
Pemanfaatkan Jamur Pelapuk Putih dan Mikroorganisme Lokal (MOL) untuk Meningkatkan Kualitas Pelepah Sawit Sebagai Pakan Ternak Kambing. [Disertasi]. Universitas Andalas. Padang

McDonald, P., R. A. Edwards, and J. P. D. Greenhalg. 2002. Animal Nutrition. sixth Ed. rentice hall. Gosport. London. Pp : 427-428.

Pazla, R. 2018. Pemanfaatan Pelepah Sawit dan Titonia (Tithonia difersivolia) dalam Ransum Kambing Peranakan Etawa untuk Menunjang Program Swasembada Susu 2020. [Disertasi]. Universitas Andalas. Padang.

Piliang, W. G. 2002. Nutrisi Vitamin. Volume I. Edisi ke-5. Institut Pertanian Bogor Press, Bogor.

Steel, R. G. D. and J. H. Torrie. 1980. Principles and Procedures of Statistics; A Biometrical Approach. 2nd Edn., McGraw Hill Book Co., New York, USA., ISBN- 13 :9780070609266, Pages: 633.

Sutardi, T. 1980. Landasan Ilmu Nutrisi Jilid I. Departemen Ilmu Makanan Ternak, Fakultas Peternakan. IPB.

Warly, L., Suyitman., Evitayani, and A, Fariani. 2017. Nutrient digestibility and apparent bioavailability of minerals in beef cattle fed with different levels of concentrate and oil-palm fronds. Pakistan Journal of Nutrition. Vol. 16 No. $3: 131-135$.

Zain, M., J. Rahman, and Khasrad. 2014. Effect of Palm Oil by Product on In Vitro Fermentation and Nutrient Digestability. Anim Nutr, Feed Technology $14: 175-181$. 